Article

\title{
Organic Corn Production Practices and Profitability in the Eastern U.S. Corn Belt
}

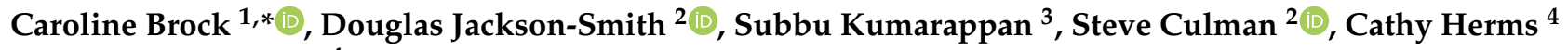 \\ and Douglas Doohan ${ }^{4}$
}

1 Department of Sociology, University of Missouri, 322 Middlebush, Columbia, MO 65211, USA

2 School of Environment and Natural Resources, The Ohio State University, 134 Williams Hall, 1680 Madison Ave., Wooster, OH 44691, USA; jackson-smith.1@osu.edu (D.J.-S.); culman.2@osu.edu (S.C.)

3 Agricultural Technical Institute, The Ohio State University, 1328 Dover Road, Halterman 089A, Wooster, OH 44691, USA; kumarappan.1@osu.edu

4 Department of Horticulture and Crop Sciences, The Ohio State University, 1680 Madison Ave., Wooster, OH 44691, USA; herms.3@osu.edu (C.H.); Doohan.1@osu.edu (D.D.)

* Correspondence: brockcc@missouri.edu; Tel.: +1-608-772-1047

check for updates

Citation: Brock, C.; Jackson-Smith, D.; Kumarappan, S.; Culman, S.;

Herms, C.; Doohan, D. Organic Corn Production Practices and Profitability in the Eastern U.S. Corn Belt. Sustainability 2021, 13, 8682. https://doi.org/10.3390/su13168682

Academic Editor: Roberto Mancinelli

Received: 31 May 2021

Accepted: 27 July 2021

Published: 4 August 2021

Publisher's Note: MDPI stays neutral with regard to jurisdictional claims in published maps and institutional affiliations.

Copyright: (c) 2021 by the authors. Licensee MDPI, Basel, Switzerland. This article is an open access article distributed under the terms and conditions of the Creative Commons Attribution (CC BY) license (https:/ / creativecommons.org/licenses/by/ $4.0 /)$.

\begin{abstract}
Efforts to assess and improve the sustainability performance of the growing organic farming sector depend on an accurate understanding of farm structure and management practices. To contribute to the dearth of literature in this area, we conducted a survey of over 850 certified organic corn growers in four states (Indiana, Michigan, Ohio, and Pennsylvania) in the spring of 2018. Findings show that most organic corn growers in this region had diversified livestock operations (mostly dairy) on relatively small farms (10-100 ha), which contrasts with trends of specialization and growth in farm size. More than half were dairy farmers, and nearly two-thirds farmed with horses (likely Amish). Soil fertility and health were managed by the use of manure, cover crops, forages, and a variety of other soil amendments. Organic corn growers relied heavily on moldboard plow tillage. All producers had positive net returns to labor and management in 2017, though net returns varied widely across operations. The results have implications for assessing the sustainability of organic farming systems, and for designing scientific research and extension/outreach programs to ensure they address the needs of the diverse organic farming population in this region.
\end{abstract}

Keywords: organic; corn; soil science; soil health; manure; profitability; crop rotation; cover crops; hay

\section{Introduction}

Organic foods have become an important component of the US food market, with sales reaching nearly $\$ 61.9$ billion in 2020 [1]. Driven by demand from organic livestock and dairy farms, land planted for organic corn in the US grew over 55\% from 2011 to 2016 (from 68,350 to 105,626 hectares), increasing more than other organic commodity grains [2-5]. In the U.S., almost all corn is feed grain used for livestock or processed for food and industrial products [6]. Farmers in the Midwestern Corn Belt and Northeast have been important to this expansion [4,7].

While land under organic management is growing rapidly, there has been growing debate over the environmental and economic sustainability of organic production systems [8-10]. Many of the sustainability advantages of organic production systems have been linked to the use of practices that promote soil health and support agroecosystem processes to help meet crop nutrient requirements and manage weeds [11]. Organic farmers are generally assumed to rely on the use of livestock manure, legume forages/cover crops, and diverse crop rotations (including perennials), to meet the nutrient needs of crops and improve soil physical properties [12-14]. Conversely, organic farmers tend to use more intensive forms of tillage due to limited options to manage weeds without synthetic 
chemicals, and that tillage can mitigate many of the soil health benefits of other organic management practices $[9,15]$.

In addition, organic conferences and/or trade shows often feature a myriad of soil amendment products designed for organic crop production, and little is known about their agronomic, environmental, and economic benefits. These amendments can be highly variable in terms of nutrient content and cost [12] and can be a significant driver of organic farm profitability [16,17] and environmental footprint [10,18]. Foreman (2014) and McBride et al. (2015) estimate that commercial fertilizers, soil conditioners, and manure comprised roughly a third of all operating cash costs for organic corn production, but they did not disaggregate specific types of soil amendments [7,19].

Although the scientific literature on the sustainability performance of organic production systems is rapidly growing, much of it is based on comparisons of a package of organic production methods with conventional methods under controlled experimental conditions. How well these representations of organic farming methods reflect reality is not clear. Organic farms can be organized and operated in many different ways. Some have argued that organic agriculture is "conventionalizing" by taking on more and more characteristics of mainstream industrial agriculture [20]. Research on "conventionalization" has explored whether the organic sector in many countries is "bifurcating" between (a) smaller-scale diversified operations that use the full range of soil health-building management practices and eschewing purchased external inputs, and (b) a commercial organic sector comprised of large-scale specialized farms that meet the minimum requirements of national organic certification programs regarding the use of some synthetic inputs but that are less likely to rely on extended crop rotations, cover crops, and other agroecological methods [20,21].

Whereas a number of studies have explored the farm structural attributes and sustainability motivations and orientations of organic farmers [20,22], there is surprisingly little information available about the range of management practices used by representative samples of working organic farms, and how this varies based on farm characteristics. Using 2010 data from a sample of 243 organic corn farms across 14 Midwestern states, McBride et al. (2015) found that organic growers managed fewer hectares, relied more on mechanical weed control, and utilized more diverse crop rotations than conventional corn farmers [7]. Compared to cultural management practices, there is even less published data on how frequently organic farmers use purchased soil amendments [23].

The present study was conducted to address gaps in our knowledge of organic corn production practices used by farmers in our study region, particularly around soil health management and the use of soil amendments. We implemented a mail survey to (i) describe organic grain farmers' soil management practices and strategies, (ii) compare the use of different practices by farm characteristics, and (iii) assess the overall economic performance of organic corn enterprises.

\section{Materials and Methods}

\subsection{Survey Sample}

We conducted a mail survey of all certified organic corn growers on the 2016 version of the USDA Organic Integrity Database in the states of Ohio, Indiana, Michigan, and Pennsylvania, USA during the early spring of 2018 [24]. These states collectively represented one-third of all U.S. organic corn growers in 2016 and raised over 20\% of the nation's organic corn [4]. According to the most recent USDA Certified Organic Survey, all four states ranked among the top 10 for corn silage acreage and yields in 2016, and among the top 12 states for grain corn acreage and yields. Of the 1662 farms included in the original sample, 167 were disqualified for various reasons, including not growing corn in 2017 (129), having undeliverable addresses (36), or no longer being engaged as farm operators (2). This produced an adjusted sample size of 1495 farms (see Supplemental Table S1). We received useable responses from 859 farms, for an overall response rate of $57.5 \%$. Response rates in each state ranged from $47 \%$ in Michigan to $66 \%$ in Indiana. The margin of error for estimates of population characteristics across the entire 4-state region was 
plus or minus 2.2\% (assuming proportion percentage $=50$ and $95 \%$ confidence level; https:/ /goodcalculators.com/margin-of-error-calculator/ accessed on 28 July 2021).

\subsection{Survey Procedures}

The survey was conducted using a modified Dillman method where multiple contacts are used to improve response rates [25]. An introductory letter explaining the purpose of the study was sent in early 2018, followed by a copy of the survey with a prepaid return envelope a week later. Farmers then received a reminder postcard about 2 weeks after the arrival of the first copy of the survey. Producers with a valid address and who did not respond to the first survey received a second copy of the survey 2 weeks after the first reminder postcard. Three weeks after the producers received a second copy of the survey, they received another reminder postcard. A third and final copy of the survey was sent to all non-respondents in early April 2018. To boost awareness and response rates, the Ohio Ecological Food and Farming Association and the Pennsylvania Association for Sustainable Agriculture promoted the survey among their clientele. Surveys were double entered and verified and subjected to a rigorous quality control screen for reasonableness and internal consistency to eliminate unreliable answers.

\subsection{Survey Content}

The survey contained detailed questions about the overall farm operation, corn management practices, and information about farmers' soil management strategies and decisionmaking. Specifically, farmers were asked to report the amount of organic cropland they farm and own, the number of years farming organically, their most important source of farm income, and if tractors or horses were used for fieldwork. In addition, we asked farmers to rank the importance of 14 different strategies or philosophies in their soil management decision-making process. See Supplemental Materials for copy of full survey instrument.

In addition to information on the whole farm, the survey asked farmers to report detailed information about a particular field on which certified organic corn was grown in 2017. They were instructed to "pick a field that is typical of the types of practices you use to raise organic corn." Systematic information about the use of various soil amendments and agronomic management practices was collected for these fields. Additionally, they were asked to report their corn yields and prices received (if sold). When corn was retained for on-farm use (not sold), we used the sample mean for market prices received reported by other farmer respondents to estimate the economic value of production. These then were used to estimate total revenue per hectare for their selected fields. Farmers were also asked to provide details about all soil amendments used on their corn field and the cost of these inputs (if purchased). This was combined with estimates of the market value of unpurchased inputs to calculate total input expenses per hectare on these corn fields. We also estimated the economic costs associated with equipment used for fieldwork based on the number of passes in the field for key farm operations reported by farmers (adjusted for the types of equipment they used), the cost of corn seeds (based on assumptions of seeding rates and market values), and the economic value of farmland (using United States Department of Agriculture (USDA) average rental rates by county). The costs of soil amendments, seeds, fieldwork, and farmland were combined to generate an estimate of total expenses per hectare for the corn enterprise. By subtracting the total expenses (as above) from the total revenues, we estimated the net returns to labor and management. Detailed information about the methods used to estimate economic values for production costs and returns is presented in the Supplemental Materials.

\subsection{Statistical Analysis}

Descriptive statistics and bivariate analyses of subgroup differences were estimated using SPSS v.26. For subgroup comparisons, our null hypothesis was that there are no differences between subgroups. The statistics presented in the tables reflect appropriate 
tests of subgroup differences. We relied on a minimum $p<0.05$ threshold to determine statistical significance. When significant, we rejected the null hypothesis and accepted that the subgroups are different from one another. For categorical variables compared across multiple groups, we reported the significance value of the chi-square statistic for the crosstabulation table relevant to the specific lines on the figure or table (e.g., distribution of farms across farm size classes by farm enterprise type, or by use/non-use of a practice). Significant chi-squared tests indicated an overall association between membership in a group and the distribution of respondents across the answer categories for that variable. For 2-group comparisons, the Fishers' Exact Test (2-sided) significance test was reported. For continuous measures (e.g., farm size or years of experience farming with organic certification) and comparisons across 3 or more subgroups (e.g., farm type), we reported the significance of the F-test for the one-way analysis of variance (ANOVA) to detect overall differences, and also reported the LSD post-hoc test for group differences that identified individual subgroup mean values that were significantly different from one another. These are denoted using subscript letters on the tables. For comparison of means across 2 subgroups (e.g., livestock vs non-livestock farms), we reported the significance value of an independent samples $t$-test.

\section{Results}

\subsection{Characteristics of Organic Corn Farms and Enterprises}

Farms growing certified organic corn in our study states were generally diversified operations that raise a number of livestock and crops in addition to corn (see Supplemental Table S2). Roughly three out of four raised livestock (76\%) and well over half milked dairy cows (59\%). Respondents raised a diverse mix of crops, including forage legumes and other hay (84\%) and a significant amount of wheat $(17 \%)$ and other small grains (33\%). Most farms were completely organic, but roughly $12 \%$ of farms were "hybrid" operations that raised both organic and conventional crops. Overall, nearly two-thirds of the respondents relied on the sale of livestock (dairy, beef, poultry, hogs, and sheep) as their primary source of income (Table 1$)$. The majority $(54 \%)$ were dairy farms that raised corn primarily as a source of feed for their cows. A minority of respondents $(27 \%)$ relied principally on the sale of corn, soybeans, and/or small grains (cash grains) as a source of farm income. Roughly $6 \%$ were farms that sold vegetables as their main farm enterprise, and $4 \%$ relied on the sale of other crops (dry beans, hay, etc.).

Table 1. Hectares of certified organic cropland operated, overall and by dominant farm enterprise.

\begin{tabular}{|c|c|c|c|c|c|c|}
\hline & \multirow[b]{2}{*}{ Overall } & \multicolumn{5}{|c|}{ Dominant Farm Enterprise } \\
\hline & & Cash Grains & Vegetables & Other Crops & Dairy & Other Livestock \\
\hline & $(\mathrm{n}=859)$ & $(n=233)$ & $(n=49)$ & $(\mathrm{n}=38)$ & $(n=465)$ & $(n=73)$ \\
\hline Mean *** & 47.8 & $75.9^{a}$ & $23.7^{b}$ & $99.2^{\mathrm{a}}$ & $34.8^{\mathrm{b}}$ & $31.5^{b}$ \\
\hline Std. Deviation & 91.7 & 124.9 & 47.8 & 155.4 & 66.2 & 45.1 \\
\hline Min & 0.8 & 2.4 & 1.2 & 2.3 & 0.8 & 0.8 \\
\hline Max & 1214 & 1012 & 283 & 769 & 1214 & 283 \\
\hline Median & 24 & 32 & 16 & 40 & 24 & 19 \\
\hline
\end{tabular}

Notes: The number of cases across the farm enterprise types does not add up to 859 because one farm failed to provide sufficient information to categorize by most important source of income. Significance test reflects ANOVA F-test for statistically significant differences across farm enterprise types where ${ }^{* * *}=p<0.001$ ). Significantly different subgroups are denoted by different letters based on LSD post-hoc tests.

Respondents operated an average of 48 hectares (median 24 ha) of certified organic cropland (Table 1). Two-thirds of producers operated between 10 and 49 ha and over three-fourths owned more than half of their farmland (Table 2). On average, farmers had been certified organic for 8 years (not shown), but over $40 \%$ had less than 5 years of certified organic experience, while nearly a third had 10 or more years (Table 2). Organic corn growers in our sample mainly raised field corn that was harvested as grain (70\%) and silage (36\%; data not shown, see Supplemental Table S2). Most organic corn was raised for on-farm use as livestock feed. About a third of farmers had sold corn from this field 
at the time they filled out the survey, while 60 percent had fed corn to livestock on their farm. Only a small minority (6\%) raised sweet corn, popcorn, seed corn, or corn for other purposes. Because some farmers said they harvested some of the field as grain, and some as silage, the total added up to more than $100 \%$.

Table 2. Percentage of respondents with key characteristics, overall and by dominant farm enterprise.

\begin{tabular}{|c|c|c|c|c|c|c|}
\hline \multirow[b]{2}{*}{ Characteristic } & \multirow[b]{2}{*}{ Overall } & \multicolumn{5}{|c|}{ Dominant Farm Enterprise } \\
\hline & & Cash Grains & Vegetables & Other Crops & Dairy & Other Livestock \\
\hline & $(\mathrm{n}=859)$ & $(n=233)$ & $(\mathrm{n}=49)$ & $(\mathrm{n}=38)$ & $(\mathrm{n}=465)$ & $(\mathrm{n}=73)$ \\
\hline \multicolumn{7}{|c|}{$\begin{array}{l}\text { Amount of certified organic } \\
\text { cropland operated }\end{array}$} \\
\hline Less than 10 ha & 14.0 & 12.2 & 37.5 & 10.8 & 10.5 & 27.4 \\
\hline 10 to 24 ha & 39.3 & 30.3 & 47.9 & 24.3 & 44.8 & 35.6 \\
\hline 25 to 49 ha & 26.6 & 22.2 & 10.4 & 21.6 & 31.8 & 21.9 \\
\hline 50 to 99 ha & 10.0 & 14.0 & 0.0 & 18.9 & 8.2 & 11.0 \\
\hline 100 ha or more & 10.0 & 21.3 & 4.2 & 24.3 & 4.8 & 4.1 \\
\hline Total $^{1}$ & 100.0 & 100.0 & 100.0 & 100.0 & 100.0 & 100.0 \\
\hline \multicolumn{7}{|c|}{$\begin{array}{l}\text { Proportion of farmland owned } \\
\text { by operator }\end{array}$} \\
\hline All & 44.5 & 45.2 & 60.4 & 42.1 & 41.9 & 47.9 \\
\hline More than half & 33.4 & 26.5 & 12.5 & 26.3 & 40.7 & 28.8 \\
\hline Less than half & 14.8 & 21.3 & 14.6 & 18.4 & 11.1 & 15.1 \\
\hline None & 7.3 & 7.0 & 12.5 & 13.2 & 6.3 & 8.2 \\
\hline Total $^{1}$ & 100.0 & 100.0 & 100.0 & 100.0 & 100.0 & 100.0 \\
\hline \multicolumn{7}{|c|}{$\begin{array}{c}\text { Years of experience farming } \\
\text { organically } * * *\end{array}$} \\
\hline Less than 3 years & 20.9 & 23.4 & 27.7 & 21.6 & 18.4 & 23.2 \\
\hline 3 to 5 years & 20.8 & 27.1 & 12.8 & 21.6 & 17.5 & 27.5 \\
\hline 6 to 9 years & 26.0 & 14.7 & 25.5 & 24.3 & 31.3 & 29.0 \\
\hline 10 to 19 years & 25.6 & 22.0 & 31.9 & 21.6 & 28.8 & 14.5 \\
\hline 20 or more years & 6.7 & 12.8 & 2.1 & 10.8 & 4.0 & 5.8 \\
\hline Total $^{1}$ & 100.0 & 100.0 & 100.0 & 100.0 & 100.0 & 100.0 \\
\hline \multicolumn{7}{|c|}{$\begin{array}{l}\text { Equipment used for fieldwork } \\
\text { operations }\end{array}$} \\
\hline Tractors & 36.5 & 63.9 & 25.5 & 65.8 & 19.7 & 49.3 \\
\hline Horses & 63.5 & 36.1 & 74.5 & 34.2 & 80.3 & 50.7 \\
\hline Total & 100.0 & 100.0 & 100.0 & 100.0 & 100.0 & 100.0 \\
\hline
\end{tabular}

Notes: ${ }^{* * *}=$ denotes statistically significant difference $(p<0.001)$ among farm types using chi-squared test. ${ }^{1}=$ Totals may not add up to 100 due to rounding.

Respondents who relied on cash grains operated more certified cropland than vegetable, dairy, and other livestock farms (Table 1). At the other end of the spectrum, growers who relied on the sale of vegetables accounted for the highest proportion of respondents operating very small farms $(<10 \mathrm{ha})$ and were most likely to own all of the land they operated (Table 2). The mean hectares of certified organic cropland reported by our respondents were representative of the total organic farm population reported in the 2016 USDA Organic Survey (United States Department of Agriculture, 2017) for each of our study states and the region as a whole (See Supplemental Table S2).

Nearly two-thirds of respondents relied on horses to do fieldwork (Table 2), which suggests they were members of Old Order Amish and Mennonite communities, denominations of Christians who make decisions around the use of technology and dress that reflect their values, such as relying on animal traction for fieldwork rather than tractors. Farmers using horse-drawn equipment (HDE) operated smaller farms (mean 20.5 ha vs. 96.0 ha; $p<0.000$ ) and only $2 \%$ operated more than 50 ha, compared to $50 \%$ of tractor farms (data not shown). HDE farms also reported fewer years of organic farming experience on average (6.2 years vs. 10.5 years; $p<0.001$; data not shown). While both HDE and tractor farmers operated a mix of different farm types, HDE farmers were more likely to 
rely on dairy farming than tractor farmers (69\% vs. $29 \% ; p<0.001)$. Conversely, a higher proportion of tractor farmers in our sample relied on cash grain sales $(47 \%$ vs. $15 \%$ for HDE farms; $p<0.001)$.

\subsection{Tillage Practices}

The majority of organic corn growers used moldboard plows and disks/harrows to prepare for planting, with relatively few practicing conservation tillage (Table 3). The majority of surveyed producers used a moldboard plow with complete inversion, whereas just under a quarter used moldboard plows without complete inversion. Chisel and vertical tillage were the most commonly practiced types of conservation tillage, and only three farms in the total sample used no-till. Cash grain farmers were somewhat more likely to use conservation tillage to prepare their organic cornfields than vegetable and dairy farmers. A variety of implements were used for cultivation. Most farms relied on row cultivators, with about a third using rotary hoes and a small number using tine weeders or cultimulchers. HDE farmers were much less likely to use conservation tillage or rotary hoes (perhaps because appropriate and affordable horse-drawn equipment is not available and/or accessible).

Table 3. Percentage of respondents reporting use of various tillage and cultivation practices on a reported cornfield in 2017.

\begin{tabular}{|c|c|c|c|c|c|c|c|c|}
\hline \multirow[b]{2}{*}{$\begin{array}{l}\text { Use of Tillage and } \\
\text { Cultivation Practices }\end{array}$} & \multicolumn{4}{|c|}{ Dominant Farm Enterprise } & \multicolumn{4}{|c|}{ Field Equipment } \\
\hline & $\begin{array}{c}\text { Total } \\
\text { Sample }\end{array}$ & Cash Grains & Vegetables & Dairy & & Horses & Tractors & \\
\hline & $(\mathrm{n}=859)$ & $(n=233)$ & $(\mathrm{n}=49)$ & $(n=465)$ & & $(\mathrm{n}=541)$ & $(\mathrm{n}=311)$ & \\
\hline Tillage & & & & & & & & \\
\hline $\begin{array}{l}\text { Moldboard plow with } \\
\text { complete inversion } \\
\text { Moldboard plow }\end{array}$ & 63.5 & 59.3 & 60.4 & 66.7 & n.s. & 66.5 & 58.2 & ** \\
\hline $\begin{array}{c}\text { without complete } \\
\text { inversion }\end{array}$ & 21.7 & 18.2 & 33.3 & 22.0 & n.s. & 26.6 & 12.9 & $* * *$ \\
\hline Any moldboard plowing ${ }^{1}$ & 84.3 & 76.6 & 91.7 & 87.9 & $* * *$ & 92.4 & 70.1 & $* * *$ \\
\hline Chisel tillage & 6.7 & 12.6 & 8.3 & 3.2 & $* * *$ & 1.1 & 16.4 & $* * *$ \\
\hline Vertical tillage & 5.7 & 6.9 & 4.2 & 5.4 & n.s. & 6.1 & 5.1 & n.s. \\
\hline Strip tillage & 0.6 & 0.9 & 2.1 & 0.2 & n.s. & 0.4 & 1.0 & n.s. \\
\hline No-till & 0.4 & 0.0 & 0.0 & 0.6 & n.s. & 0.4 & 0.3 & n.s. \\
\hline Any conservation tillage ${ }^{2}$ & 12.8 & 19.0 & 12.5 & 9.5 & $* *$ & 7.9 & 21.2 & $* * *$ \\
\hline Disk/Harrow & 82.9 & 80.5 & 83.3 & 84.2 & n.s. & 83.4 & 82.3 & n.s. \\
\hline Subsoiling & 2.1 & 3.9 & 2.1 & 1.5 & n.s. & 1.1 & 3.9 & $* *$ \\
\hline Rototiller & 2.1 & 0.4 & 2.0 & 3.4 & n.s. & 2.0 & 2.3 & n.s. \\
\hline \multicolumn{9}{|l|}{ Cultivation } \\
\hline Row cultivator & 92.4 & 95.2 & 83.3 & 91.6 & * & 92.4 & 92.6 & n.s. \\
\hline Rotary hoe & 30.3 & 51.5 & 14.6 & 19.9 & $* * *$ & 13.9 & 58.8 & $* * *$ \\
\hline Tine weeder/harrow & 8.5 & 9.9 & 10.2 & 7.3 & n.s. & 7.4 & 10.6 & n.s. \\
\hline Cultimulcher & 5.0 & 7.7 & 2.0 & 4.3 & n.s. & 6.5 & 2.3 & $* *$ \\
\hline
\end{tabular}

Note: ${ }^{1}=$ Combines both categories. ${ }^{2}=$ Uses any of the four types of conservation tillage. Chi-square significance test results for subgroup differences by farm enterprise type or use of horses or tractors for field operations denoted by: $n . s=$ not significant; ${ }^{*}=p<0.05 ;{ }^{* *}=p<0.01$; $* * *=p<0.001$.

\subsection{Crop Rotations and Cover Crops}

Organic corn farmers in our sample used diverse crop rotations involving soybeans, small grains, hay, pasture, or fallow (Table 4). The most common rotation practiced by $38 \%$ of the producers was 3 years of hay followed by 1 year of corn (HHHC). The next most common rotation included 2 years of hay followed by 2 years of corn (HHCC). An important attribute of many of the farmers' rotations was that nearly all rotated to a crop 
other than corn over the previous 3 years on fields where organic corn was grown in 2017 (2014-2016). Another important attribute of the rotations was that most farmers incorporated some hay crops in their 4-year rotation, with over two-thirds incorporating 2 to 3 years of hay in the rotation before planting corn in 2017. A third important attribute was that small grains were used in rotation with corn on roughly a quarter of farms, whereas soybeans were rotated into corn fields on roughly $20 \%$ of study farms. Livestock farmers (in particular, dairy farms) were much more likely to incorporate hay into the rotations. Compared to farmers who used tractors, HDE farmers raised more hay and fewer soybeans and small grains.

Table 4. Percentage of organic corn growers using different crop rotations on their 2017 corn fields (accounts for 2014-2017).

\begin{tabular}{|c|c|c|c|c|c|c|c|c|c|c|c|}
\hline \multirow[b]{2}{*}{ 4-Year Rotations } & \multicolumn{4}{|c|}{$\begin{array}{l}\text { Presence of } \\
\text { Livestock }^{+}\end{array}$} & \multicolumn{3}{|c|}{ Dominant Farm Enterprise } & \multicolumn{4}{|c|}{ Field Equipment } \\
\hline & $\begin{array}{c}\text { Total } \\
\text { Sample }\end{array}$ & Yes & No & & $\begin{array}{l}\text { Cash } \\
\text { Grains }\end{array}$ & Vegetables & Dairy & & Horses & Tractors & \\
\hline & $(\mathrm{n}=859)$ & $(n=652)$ & $(n=206)$ & & $(n=233)$ & $(\mathrm{n}=49)$ & $(n=465)$ & & $(\mathrm{n}=541)$ & $(n=311)$ & \\
\hline \multicolumn{12}{|l|}{$\begin{array}{l}\text { Most common } \\
\text { rotations } \ddagger\end{array}$} \\
\hline H-H-H-C & 38.2 & 45.3 & 27.0 & $* * *$ & 26.2 & 20.4 & 47.1 & $* * *$ & 43.4 & 28.9 & $* * *$ \\
\hline $\mathrm{H}-\mathrm{H}-\mathrm{C}-\mathrm{C}$ & 16.9 & 21.1 & 10.2 & $* * *$ & 9.4 & 6.1 & 22.6 & $* * *$ & 23.3 & 5.8 & $* * *$ \\
\hline Sg-H-H-C & 4.8 & 6.1 & 2.4 & $*$ & 2.6 & 4.1 & 6.5 & n.s. & 5.7 & 3.2 & n.s. \\
\hline C-S-Sg-C & 4.7 & 1.0 & 10.5 & $* * *$ & 14.2 & 2.0 & 0.0 & $* * *$ & 0.7 & 11.6 & $* * *$ \\
\hline S-C-S-C & 2.8 & 0.8 & 6.0 & $* * *$ & 7.3 & 2.0 & 0.2 & $* * *$ & 0.7 & 6.4 & $* * *$ \\
\hline $\mathrm{C}-\mathrm{H}-\mathrm{H}-\mathrm{C}$ & 2.4 & 3.0 & 1.5 & n.s. & 1.3 & 2.0 & 3.0 & n.s. & 3.0 & 1.6 & n.s. \\
\hline $\mathrm{H}-\mathrm{C}-\mathrm{C}-\mathrm{C}$ & 2.2 & 2.9 & 0.0 & $*$ & 0.0 & 0.0 & 3.7 & $* *$ & 3.1 & 0.3 & $* *$ \\
\hline C-Sg-H-C & 2.2 & 2.9 & 1.2 & n.s. & 0.9 & 2.0 & 2.8 & n.s. & 1.1 & 4.2 & $* *$ \\
\hline \multicolumn{12}{|l|}{$\begin{array}{l}\text { Key attributes of crop } \\
\text { rotations on field over } \\
\text { previous } 3 \text { years }\end{array}$} \\
\hline Any additional corn & 44.4 & 42.2 & 51.8 & $*$ & 52.2 & 36.4 & 41.0 & $*$ & 42.0 & 48.7 & $*$ \\
\hline Any soybeans & 19.9 & 12.7 & 43.1 & $* * *$ & 46.5 & 13.6 & 4.8 & $* * *$ & 6.3 & 43.8 & $* * *$ \\
\hline Any small grains & 24.1 & 19.5 & 38.6 & $* * *$ & 38.1 & 34.1 & 14.3 & $* * *$ & 13.2 & 43.1 & $* * *$ \\
\hline Any hay & 81.9 & 89.0 & 58.9 & $* * *$ & 61.1 & 63.6 & 95.6 & $* * *$ & 93.1 & 62.2 & $* * *$ \\
\hline 2 or more years of hay & 68.7 & 76.1 & 44.7 & $* * *$ & 46.0 & 50.0 & 84.4 & $* * *$ & 83.2 & 43.8 & $* * *$ \\
\hline $\begin{array}{c}\text { No additional corn or } \\
\text { soybeans }\end{array}$ & 48.5 & 52.4 & 35.5 & $* * *$ & 33.2 & 59.1 & 56.6 & $* * *$ & 55.2 & 36.8 & $* * *$ \\
\hline
\end{tabular}

Notes: $\mathrm{H}=$ hay; $\mathrm{C}=$ corn; $\mathrm{S}=$ soybeans; $\mathrm{Sg}=$ small grain; ${ }^{\dagger}=$ Does not include horses not raised for sale; ${ }^{\ddagger}=$ Only 4 -year rotation combinations reported by more than $2 \%$ of respondents are shown here. Chi-square significance tests for group differences denoted as: n.s. $=$ not significant; ${ }^{*}=p<0.05 ;{ }^{* *}=p<0.01 ;{ }^{* * *}=p<0.001$.

Overall, roughly four in ten organic corn growers used cover crops before planting corn (Table 5). Non-livestock farmers were more likely to use cover crops than farms with livestock. Similarly, cash grain and vegetable farmers used cover crops more than dairy farmers. Tractor farmers were somewhat more likely than HDE farmers to plant cover crops. Farmers reported using a variety of different kinds of cover crops. The most prevalent were grasses (e.g., rye, triticale, and oats), which were planted by over half of the respondents who used cover crops. Some farmers also planted legumes as cover crops (e.g., clovers, vetch, and peas). Livestock farms were more likely to use grasses as cover crops. 
Table 5. Percentage of organic corn growers using cover crops by presence of livestock, dominant enterprise, and use of horses.

\begin{tabular}{|c|c|c|c|c|c|c|c|c|c|c|c|}
\hline & \multicolumn{4}{|c|}{$\begin{array}{c}\text { Presence of } \\
\text { Livestock }\end{array}$} & \multicolumn{3}{|c|}{ Dominant Farm Enterprise } & \multicolumn{4}{|c|}{ Field Equipment } \\
\hline & $\begin{array}{c}\text { Total } \\
\text { Sample }\end{array}$ & Yes & No & & $\begin{array}{l}\text { Cash } \\
\text { Grains }\end{array}$ & Vegetables & Dairy & & Horses & Tractors & \\
\hline & $(\mathrm{n}=859)$ & $(\mathrm{n}=652)$ & $(n=206)$ & & $(n=233)$ & $(\mathrm{n}=49)$ & $(n=465)$ & & $(\mathrm{n}=541)$ & $(\mathrm{n}=311)$ & \\
\hline $\begin{array}{l}\text { Used any cover crops } \\
\text { prior to planting corn in } \\
2017^{+}\end{array}$ & 41.7 & 38.5 & 51.9 & $* * *$ & 48.3 & 51.0 & 37.7 & * & 37.8 & 48.6 & * \\
\hline $\begin{array}{l}\text { Type of cover crop used } \ddagger \\
\text { (\% of farms with any cover } \\
\text { crops) }\end{array}$ & & & & $* * *$ & & & & $* * *$ & & & $* * *$ \\
\hline Grasses & 52.4 & 55.6 & 44.8 & & 42.0 & 45.8 & 61.8 & & 61.9 & 39.3 & \\
\hline Legumes & 20.4 & 14.1 & 35.2 & & 34.8 & 20.8 & 6.4 & & 7.9 & 37.3 & \\
\hline Forbs & 1.1 & 1.2 & 1.0 & & 0.0 & 4.2 & 1.2 & & 20.0 & 0.0 & \\
\hline Mix of Above & 26.1 & 29.0 & 19.0 & & 23.2 & 29.2 & 30.6 & & 28.2 & 23.3 & \\
\hline
\end{tabular}

Notes: Totals may not add up to 859 due to missing data used to categorize farms by presence of livestock, dominant farm enterprise, or use of horses and tractors. $^{\dagger}=$ Excludes hay in field prior to planting corn. ${ }^{\ddagger}=$ We defined forbs as any broadleaf cover crop, excluding legumes; mixes included more than one category (grass, legume, forb). Chi = square significance test results for subgroup differences denoted by: ${ }^{*}=p<0.05 ;{ }^{* *}=p<0.001$.

Combining the results in Tables 4 and 5, a pattern emerged in which organic livestock farmers were more likely to use hay in their corn rotations, but less likely to use cover crops. Conversely, organic cash grain and vegetable farmers used more cover crops but were less likely to rotate a perennial forage into their corn fields. The proportions of livestock vs. non-livestock farms that used either cover crops or hay (or both) in crop rotations on corn fields are shown in Figure 1. A significantly larger share of livestock farms (93\%) used cover crops and/or hay in rotation than the organic farms that had no livestock (85\%; Fishers' Exact Test, $p<0.000)$.

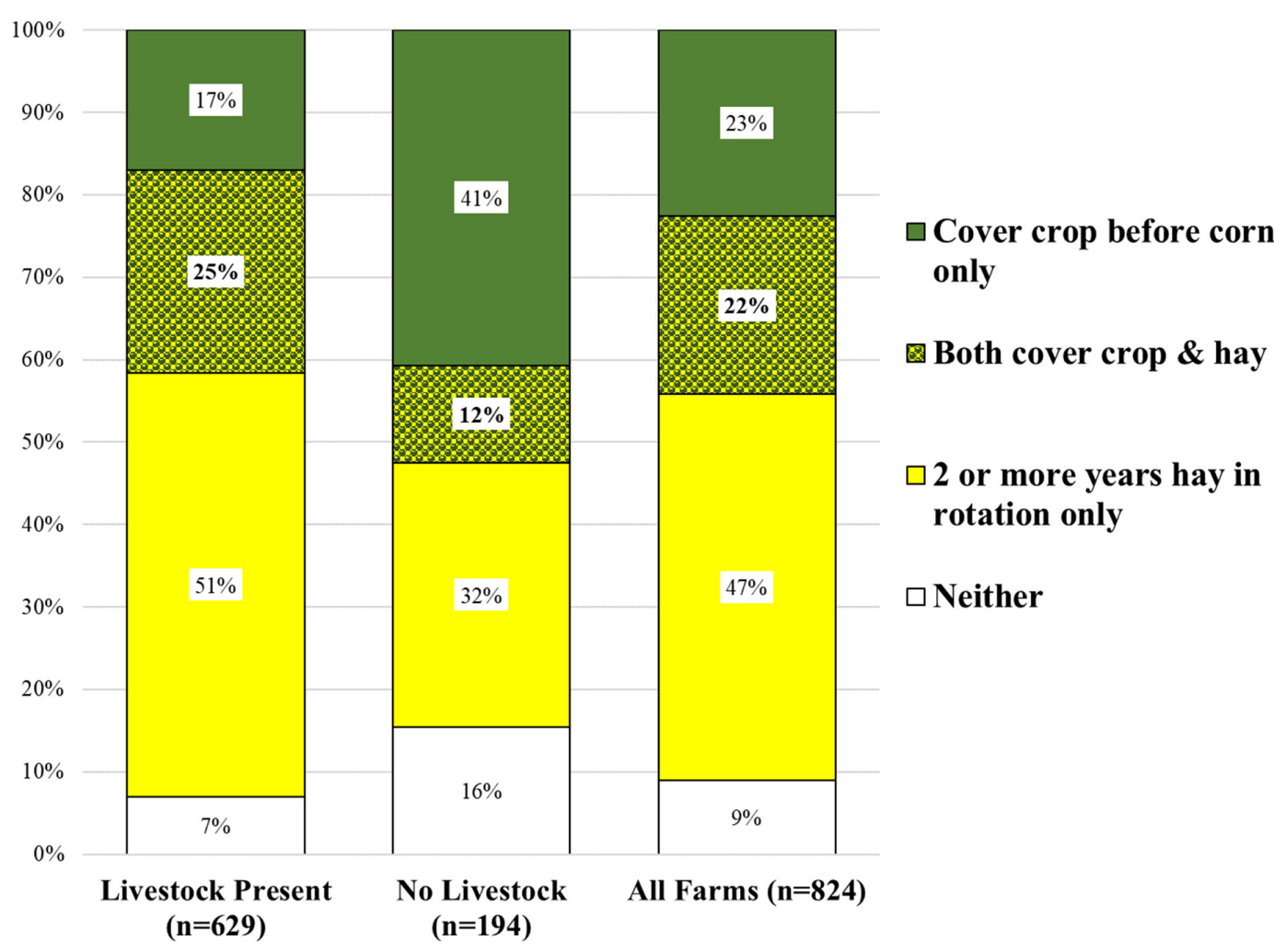

Figure 1. Use of cover crops and hay in crop rotation on organic corn farms, by presence of livestock. Note: Chi-squared test results suggest that the presence or absence of livestock is significantly related to the distribution of farms across the four categories $(p<0.000)$. 


\subsection{Use of Soil Amendments}

The vast majority of organic corn growers in our sample relied on manure and/or compost to provide essential crop nutrients and build soil quality (Table 6). Overall, nearly $90 \%$ of organic growers reported applying some kind of manure prior to planting corn, usually cattle or chicken manure. About one in ten farmers applied compost. For about a third of farmers, manure was the only soil amendment used before planting corn in 2017. Organic Materials Review Institute (OMRI) approved commercial fertilizer products that include nitrogen $(\mathrm{N})$, phosphorus $(\mathrm{P})$, and potassium $(\mathrm{K})$ nutrients were applied by over 40 percent of respondents. About a quarter of the farmers applied micronutrients, particularly boron, and roughly one in five applied some kind of microbial stimulant or inoculant to their cornfield. Just under a third of our survey respondents applied some type of calcium amendment to their corn fields in 2017. Because calcium is often applied only once every few years, we also solicited information about calcium amendments on these fields over the three previous years (2014-2016). Roughly half of organic farmers applied some form of calcium amendment over the last 4 years, with most using gypsum or high-calcium lime formulations, and $11 \%$ using regular agricultural lime products.

Table 6. Percentage of organic corn growers applying soil amendments to corn field in 2017, by farm characteristics.

\begin{tabular}{|c|c|c|c|c|c|c|c|c|c|c|c|}
\hline & \multicolumn{4}{|c|}{ Presence of Livestock } & \multicolumn{3}{|c|}{ Dominant Farm Enterprise } & \multicolumn{4}{|c|}{$\begin{array}{l}\text { Type of Field } \\
\text { Equipment }\end{array}$} \\
\hline & $\begin{array}{c}\text { Total } \\
\text { Sample }\end{array}$ & Yes & No & & $\begin{array}{l}\text { Cash } \\
\text { Grain }\end{array}$ & Vegetables & Dairy & & Horse & Tractor & \\
\hline & $(\mathrm{n}=859)$ & $(\mathrm{n}=652)$ & $(n=206)$ & & $(\mathrm{n}=233)$ & $(\mathrm{n}=49)$ & $(\mathrm{n}=465)$ & & $(\mathrm{n}=541)$ & $(\mathrm{n}=311)$ & \\
\hline $\begin{array}{c}\text { Inputs used on corn in } 2017 \\
\text { Any livestock manure }\end{array}$ & 89.2 & 91.4 & 82.0 & $* * *$ & 81.1 & 79.6 & 95.3 & $* * *$ & 93.5 & 82.0 & $* * *$ \\
\hline Any compost & 11.2 & 9.5 & 16.5 & $* *$ & 17.2 & 18.4 & 6.7 & $* * *$ & 8.1 & 16.1 & $* * *$ \\
\hline Any purchased NPK input & 42.1 & 42.2 & 42.2 & n.s. & 40.3 & 51.0 & 43.0 & n.s. & 42.0 & 42.8 & n.s. \\
\hline Sulfur & 12.2 & 13.3 & 8.7 & $*$ & 12.0 & 6.1 & 13.5 & n.s. & 12.8 & 11.6 & n.s. \\
\hline Any micronutrients & 24.7 & 26.4 & 18.9 & * & 21.5 & 18.4 & 28.4 & n.s. & 25.7 & 23.2 & n.s. \\
\hline Boron & 13.1 & 14.6 & 8.7 & * & 9.0 & 8.2 & 15.7 & $*$ & 14.0 & 11.9 & n.s. \\
\hline Any calcium $(\mathrm{Ca})$ input $^{+}$ & 28.7 & 26.2 & 29.3 & n.s. & 28.3 & 34.7 & 29.2 & n.s. & 29.4 & 27.7 & n.s. \\
\hline Ag Lime & 3.8 & 4.3 & 2.4 & n.s. & 3.9 & 0.0 & 4.3 & n.s. & 3.5 & 4.5 & n.s. \\
\hline High-Ca lime & 12.3 & 12.6 & 11.7 & n.s. & 10.7 & 24.5 & 13.8 & $*$ & 14.8 & 8.4 & $* *$ \\
\hline Gypsum & 14.8 & 14.1 & 16.0 & n.s. & 19.7 & 16.3 & 13.3 & n.s. & 13.3 & 17.0 & n.s. \\
\hline $\begin{array}{l}\text { Microbial stimulants \& } \\
\text { inoculants }\end{array}$ & 20.0 & 19.2 & 22.3 & n.s. & 21.5 & 20.4 & 19.6 & n.s. & 17.9 & 23.8 & * \\
\hline Foliar-applied inputs & 13.7 & 12.6 & 17.0 & n.s. & 16.3 & 20.4 & 12.7 & n.s. & 12.8 & 15.1 & n.s. \\
\hline \multicolumn{12}{|l|}{$\begin{array}{l}\text { Calcium inputs used on } \\
\text { field last } 4 \text { years (2014-2017) }\end{array}$} \\
\hline Any Ca input ${ }^{+}$ & 50.6 & 52.6 & 44.2 & * & 45.9 & 46.9 & 42.1 & n.s. & 52.5 & 47.6 & n.s. \\
\hline Lime & 11.4 & 11.4 & 9.2 & n.s. & 9.4 & 4.1 & 12.7 & n.s. & 10.5 & 13.2 & n.s. \\
\hline High-Ca lime & 25.5 & 26.8 & 21.4 & n.s. & 20.6 & 28.6 & 30.1 & $*$ & 29.4 & 18.3 & $* * *$ \\
\hline Gypsum & 25.3 & 26.1 & 22.3 & n.s. & 24.5 & 22.4 & 26.5 & n.s. & 24.4 & 27.0 & n.s. \\
\hline
\end{tabular}

Notes: ${ }^{\dagger}=$ includes any application of ag lime, High-Ca lime, gypsum, or dolomite. Chi = square significance tests for use/non-use of practice across subgroups where ${ }^{*}=p<0.05 ;^{* *}=p<0.01 ;^{* * *}=p<0.001$.

There were some modest differences in soil amendment practices among different farm types, but few were statistically significant. Compost use was more common among farmers without livestock than those with livestock. Nevertheless, most non-livestock farms still applied manure to their corn fields (typically purchased or received from neighboring farms), and they were much more likely to use chicken manure than livestock farms (52.4\% vs. $29.0 \%, p<0.001)$.

\subsection{Soil Management Strategies}

The five soil management considerations most frequently rated as "very important" for organic farmers as they make soil management decisions included: a focus on building soil health, building organic matter content, avoiding soil compaction, using tillage to control weeds, and utilizing manure and compost to provide nutrients for crops. The considerations that received the lowest importance ratings related to the use of cover crops to control weeds, the use of microbial stimulants and inoculants, and the addition of calcium products to balance base cations (i.e., "soil balancing"). Farmers were asked to indicate how important 14 different considerations were to their soil management decision- 
making. For each consideration, respondents were given four answer choices: "not at all important," "somewhat important," "important," and "very important." The percentage of respondents who rated each of the 14 considerations from "not at all important" to "very important" is shown in Figure 2 below. All of the considerations were rated as important or very important by at least two-thirds of the organic growers in our survey.

I believe building healthier soils can ensure healthier crops

I seek to build the organic matter content of my soils over time

It is very important to me to reduce soil compaction

I pick tillage practices based on their impacts on weed population

I prefer to use manure and compost as a source of soil nutrients

I use cover crop based on their ability to build soil quality

I choose crop rotations based on whether they improve soil quality over time

I choose crop rotations based on their ability to break pest and disease cycles

I ensure that soil nutrient levels are sufficient to meet crop needs

I pick tillage practices based on their impacts on soil quality

I try to replace the nutrients that are removed by crops

I use cover crops based on their ability to control weeds

I add soil amendments specifically to increase, stimulate, and/or diversify soil microbial populations

I try to keep soil calcium saturation at roughly $65-75 \%$ and magnesium at $10-15 \%$

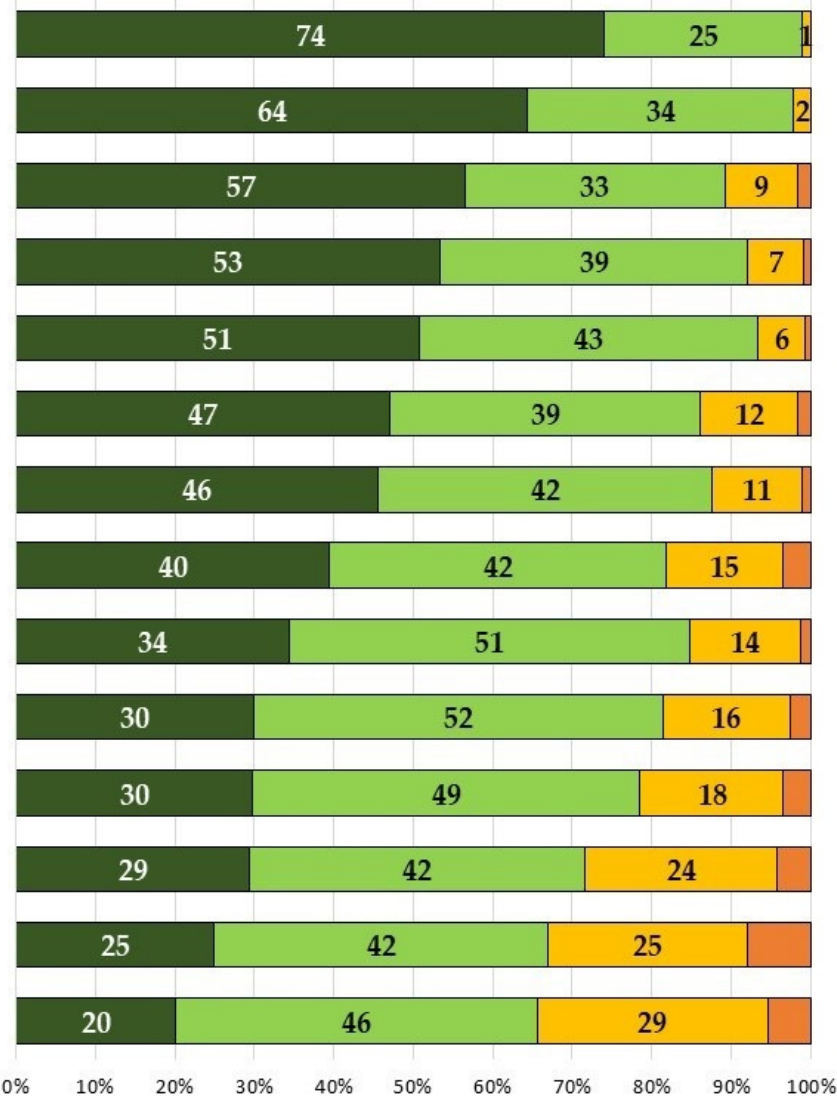

$\square$ Somewhat important $\square$ Not at all important

Figure 2. Percentage of organic corn growers indicating how important different soil management considerations are to their operations.

\subsection{Economic Performance of Organic Corn Enterprises}

In this section, we summarize the estimated economic costs and returns for the corn enterprise among the 526 respondents who harvested their organic corn as grain in 2017 and provided complete information on revenues and expenses for their organic corn crop. Complete data for corn enterprise income and revenues were gathered from 749 farms in our sample.

Estimated Yields and Revenues: The mean corn yield on these farms was $8.41 \mathrm{Mg} \mathrm{ha}^{-1}$ ( $\mathrm{sd}=2.68$; data not shown). This is higher than the $7.4 \mathrm{Mg} \mathrm{ha}^{-1}$ for organic corn grain estimated for this region in the USDA 2016 Organic Survey [5]. There was significant variability across our sample. Corn grain yields ranged from 1.57 to $15.57 \mathrm{Mg} \mathrm{ha}^{-1}$. The subset of respondents who had already sold their corn crop $(n=261)$ reported an average market price of USD \$374.06 $\mathrm{Mg}^{-1}$ ( $\mathrm{sd}=$ \$56.86; data not shown). We combined information about yields and market prices to estimate the economic value of the 2017 corn crop for all farms in the sample. For farmers who had not yet sold any corn as grain, we used the mean sample price. As shown in Table 6, the mean total economic value of organic corn harvested as grain in our sample was $\$ 3130 \mathrm{ha}^{-1}(\mathrm{sd}=\$ 1045)$. 
Estimated Expenses: On average, organic farmers who harvested corn as grain had economic costs worth a total of $\$ 370 \mathrm{ha}^{-1}(\mathrm{sd}=\$ 255)$ from soil amendments for their corn fields (Table 7). Economic costs were highest for manure and compost, which were applied by over $90 \%$ of farms, with an average charge of $\$ 201 \mathrm{ha}^{-1}$. When averaged across all farms, organic NPK fertilizer products cost an average of $\$ 66 \mathrm{ha}^{-1}$. However, these were used by just $32 \%$ of farms (Table 6); therefore, mean expenses were $\$ 207$ ha $^{-1}$ for the subset of farms that applied them (data not shown). Expenditures for calcium amendments averaged $\$ 33 \mathrm{ha}^{-1}$ across all farms (Table 7) but were incurred by only $17 \%$ of farms (Table 6), and these farms spent an average of $\$ 125 \mathrm{ha}^{-1}$ on these products (data not shown).

Table 7. Average organic corn production expenses, total revenue, and net returns to labor and management per hectare (for organic farms harvesting corn for grain in 2017, $\mathrm{n}=526$ ).

\begin{tabular}{|c|c|c|c|c|}
\hline Economic Variable & Mean & Std. Dev. & Min & Max \\
\hline Soil Amendments & \multicolumn{4}{|c|}{ USD \$ per hectare } \\
\hline Manure \& Compost & $\$ 201.09$ & $\$ 164.99$ & $\$ 0.00$ & $\$ 1235.53$ \\
\hline NPK Fertilizers & $\$ 66.00$ & $\$ 127.08$ & $\$ 0.00$ & $\$ 1235.53$ \\
\hline Calcium Products & $\$ 33.48$ & $\$ 86.03$ & $\$ 0.00$ & $\$ 680.66$ \\
\hline Micronutrients & $\$ 16.83$ & $\$ 51.56$ & $\$ 0.00$ & $\$ 473.95$ \\
\hline Microbial Stimulants/Inoculants & $\$ 9.97$ & $\$ 43.98$ & $\$ 0.00$ & $\$ 822.86$ \\
\hline Fish and Foliar Products & $\$ 14.18$ & $\$ 42.01$ & $\$ 0.00$ & $\$ 294.06$ \\
\hline Other Soil Amendments & $\$ 28.66$ & $\$ 113.28$ & $\$ 0.00$ & $\$ 1124.33$ \\
\hline Total Soil Amendment Costs & $\$ 370.21$ & $\$ 254.71$ & $\$ 17.17$ & $\$ 1606.18$ \\
\hline Estimated Land Costs & $\$ 374.65$ & $\$ 195.35$ & $\$ 24.71$ & $\$ 1282.64$ \\
\hline Estimated Fieldwork Costs & $\$ 245.46$ & $\$ 101.43$ & $\$ 27.13$ & $\$ 590.45$ \\
\hline Estimated Seed Costs & $\$ 237.13$ & $\$ 47.45$ & $\$ 131.79$ & $\$ 264.58$ \\
\hline Total Economic Costs & $\$ 1227.45$ & $\$ 376.58$ & $\$ 534.16$ & $\$ 3088.82$ \\
\hline Total Revenue & $\$ 3130.43$ & $\$ 1044.82$ & $\$ 481.86$ & $\$ 6523.58$ \\
\hline Net Returns to Labor and Management & $\$ 1902.98$ & $\$ 983.32$ & $-\$ 1257.85$ & $\$ 5090.19$ \\
\hline
\end{tabular}

In addition to the economic cost of soil amendments and fertilizer applications, we estimated the value of three other major categories of corn production expenses for each of our study farms: land costs, fieldwork, and seed purchases. Results suggest that soil amendments accounted for 30 percent of total estimated economic costs of corn production on our study farms (Table 6). Imputed costs of land, fieldwork, and seed costs accounted for 31, 20, and 19 percent of total costs, respectively.

When total costs are balanced against revenues from corn grain, our findings indicate that organic farmers in this region received average net returns to labor and management of $\$ 1903$ per hectare (median $=\$ 1928)$ in 2017 (Table 6). Net returns varied widely by farm but were distributed normally (Kolmogorov-Smirnov test $p=0.200$; Shapiro-Wilk $p=0.830$ ), ranging from a net loss of $-\$ 1257$ to a net gain of $\$ 5090$ per hectare (Figure 3). Excluding the top and bottom 10 percent of producers, the vast majority of farmers received a net return between $\$ 709$ and $\$ 3154$ per hectare. 


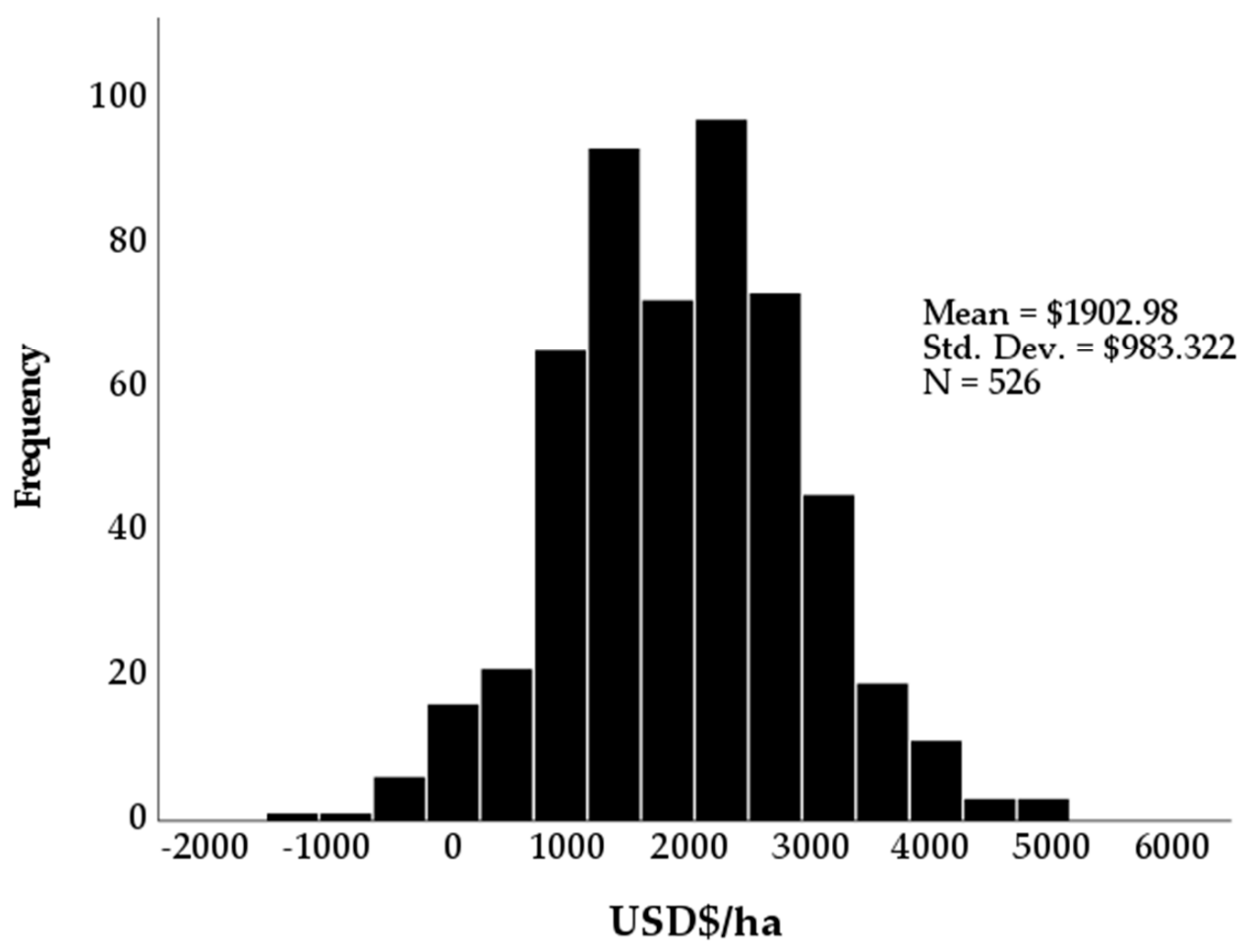

Figure 3. Distribution of farms by net returns to labor and management, for organic farms harvesting corn as grain in 2017.

\section{Discussion}

This study is one of the most in-depth and comprehensive efforts to document the complex and diverse agronomic and soil management practices utilized by the rapidly growing organic corn farm sector, which have implications for sustainability. Little research documenting on-farm practices of organic farmers has been published [7], and much of the agronomic and soils-related organic research has been based on experimental trials conducted on university research stations [26]. Contrary to the expectations of "conventionalization" scholars, the vast majority of organic corn growers in this region operate at a scale, level of diversification, and manner of utilizing agroecological practices that run counter to trends toward consolidation and specialization in organic systems found elsewhere $[7,20,27]$.

Organic corn farms in this sample operated relatively modest acreages, which likely reflects the fact that most respondents were integrated crop-livestock operations (mainly dairies). While this sample was representative of this region in terms of farm size, organic farms in this region tend to be smaller on average than the national average [7]. Within this sample, cash grain operators farmed significantly more organic cropland than farmers who raised corn as part of a livestock operation. The high level of land ownership found among organic corn farms in our sample may also reflect the high investments and commitment involved with the 3-year transition required for organic certification [28] and the land tenure security required to run an integrated crop-livestock operation [29]. Most organic corn was harvested as field corn to be fed to on-farm livestock as grain or silage. The presence of livestock on most farms in this study enabled them to utilize more perennials and diverse crop rotations and maximize the use of farm-produced manure as a critical nutrient and soil amendment.

The smaller farm sizes found in our study also reflect the fact that horses were used for field operations by nearly two-thirds of our respondents, most of whom we presume were members of Old Order Amish communities. Their reliance on horses and desire to live in close proximity to each other may encourage Old Order Amish farms to be smaller than non-Amish farms that rely on tractors for fieldwork [30]. As other dairy 
farmers exit, the percentage of Amish-owned farms has increased in states with heavy Amish populations [30]. Given that the Amish population doubles every 20 years, and they primarily reside in rural areas, this trend may continue [31]. Contrary to popular conceptions, most Amish farmers do not sell certified organic products. However, there is a strong organic movement among a subset of the Amish who view organic farming as a good way to remain economically viable and stay consistent with their values of family farming and stewardship of the earth [32].

Our analysis of economic costs and returns suggests that most organic corn grain growers in our sample had positive returns to labor and management in 2017, a result consistent with several recent studies of profitability in organic agriculture [7,8]. The majority had positive net returns (97\%), and 82 percent had net returns over $\$ 1000 \mathrm{ha}^{-1}$. Positive net returns are a function of higher commodity prices, because U.S. prices for conventional corn in 2017 were $\$ 127 \mathrm{Mg}^{-1}$, over 65\% lower than prices received for organic corn [33]. Some have argued that organic farmers have lower production costs [16]. However, based on our survey results, organic corn enterprise variable costs (seeds, soil amendments) appear to be similar to those incurred by conventional corn growers in this region in 2017 [34].

Overall, the heavy use of diverse crop rotations and reliance on cover crops is consistent with previous studies of organic farmers and in striking contrast to the management practices used by conventional corn growers, who rely principally on alternating corn with soybeans or growing corn for several years in a row [7].

Cover crops are increasingly recommended as a way to improve soil physical properties, increase soil organic matter and biological activity, prevent loss of soil and nutrients, and control weeds [35,36]; perenniality can also provide some of those same benefits [37]. Nearly half of our respondents also reported the use of cover crops in the winter prior to planting corn, significantly higher than adoption rates reported by conventional grain growers $[38,39]$. There was a definite difference in forage and cover crop use by farm type. Organic corn growers with livestock were much more likely to incorporate perennial forages into their crop rotation, and as a result, were less likely to use cover crops. By contrast, growers who did not raise livestock had less diverse crop rotations and fewer perennials in rotation but were more likely to use annual cover crops. Both approaches offer potential soil health benefits, but livestock producers can utilize perennial hay crops as a feed source.

Tillage is a primary means of weed control for organic grain farmers compared to the current widespread use of no-till planting methods, a trend that has been facilitated by the use of genetically engineered corn varieties that are resistant to glyphosate herbicide, an option not available to organic farmers $[40,41]$. Not surprisingly, no-till and conservation tillage approaches were used by only a tiny fraction of our respondents, which is consistent with a 2015 national study of organic field corn growers that found 65\% of the growers used a moldboard plow and only 5\% used a no-till planter [7].

Farmers expressed soil management philosophies that reflect greater reliance on agroecological processes to manage weed, pest, and crop fertility challenges. Nearly a third of farmers relied on manure as their only amendment on fields being planted to corn. Our findings are broadly consistent with the results of one recent national study [7], which found that $75 \%$ of U.S. organic corn growers used some kind of manure (compared to $90 \%$ in our sample), and roughly half used commercial certified organic fertilizers (compared to $42 \%$ in our sample). Meanwhile, significant numbers of organic producers reported use of purchased soil amendments that are often recommended by proponents of biological or regenerative agriculture [42-44], which some may characterize as an "input substitution" approach that has been linked to conventionalization in the organic sector (e.g., $[20,22]$ ). Among our respondents, between 20-25\% reported use of micronutrients or microbial stimulants/inoculants, and 10-14\% applied foliar products, fish fertilizers, sulfur, or boron on their corn fields. 
Organic grain farmers indicated that building soil health and organic matter were their most important soil management considerations. This is consistent with previous research that focused on organic vegetable producers [45]. Interest in soil health is also becoming more important to conventional farmers [39]. Previous work has demonstrated that many organic producers have a strong interest in soil health and programs and resources that can help them assess how different soil amendments, crop rotations, and tillage practices interact to impact soil health and agronomic outcomes would likely be welcomed $[26,45]$. At the same time, soil management decisions by organic farmers reflect more than just a focus on soil health. For example, their decisions about tillage are driven more by a desire to control weeds than by impacts on soil quality. Similarly, the choice of crop rotations reflects a mix of goals-including improving soil quality but also breaking pest and disease cycles.

This study has several limitations and a number involve the complications of economic calculations from farm survey data as outlined in our supplemental materials. First, we did not include several categories of economic costs that might be considered in a traditional profitability analysis (e.g., utility and energy expenses, storage and transport costs, interest expenses, and insurance costs). These unmeasured costs usually account for $25 \%$ of typical corn variable costs in Ohio [34]. Additionally, our results are for a single 2017 cornfield reported by farmers in the survey. Differences in market and weather conditions can affect yields, revenues, and costs over time. For example, organic corn prices dropped by nearly $25 \%$ between 2017 and 2020, a reflection of reduced demand from a stagnant organic dairy sector and oversupply from new entrants into the organic feed corn market [24]. Finally, there are few datasets and published methods for estimating the costs of fieldwork for farms that utilize horses instead of tractors. Given that nearly two-thirds of our sample consisted of these types of farms, conventional assumptions about the economic costs of machinery ownership and use (and relative labor time required per hectare) may not apply. Another limitation was focusing the analysis primarily on corn, as many of the farms in our study were integrated livestock operations so assessing profitability may involve different calculations [46].

Future research should further explore agronomic, economic, and sustainability issues of organic corn production systems that this study was unable to fully address. For example, analyses of the use of specific inputs are associated with agronomic or economic benefits. Most organic grain farmers still rely heavily on moldboard plowing for tillage, and there is evidence that tillage can undermine the positive benefits of organic management on soil health [47-49]. There are significant challenges to managing weeds without synthetic chemicals; possibilities exist for combining cover cropping, mulching, and mechanical methods, but more research is needed in conjunction with farmers to work through unknowns and complications [15]. Future research on the use of conservation tillage in the context of organic farming could provide important insights for adapting current systems and improving the environmental footprint of organic corn production [47-49]. Likewise, producers use a wide range of purchased products on their organic corn fields, many of which have received little attention from the scientific community [50] and should be further explored in terms of their agronomic and economic benefits for farmers.

Given the significant number of Amish organic corn farmers in these states, organic farming outreach programs should consider ways to adapt content to the unique cultural and religious beliefs of this population, and modes of dissemination should focus on or include printed products and in-person farmer meetings [51]. While national studies suggest that organic farmers had higher levels of formal education than conventional farmers [7], Amish producers traditionally prefer experiential and home-based learning, have lower levels of formal schooling, and English is typically their second language [52]. Therefore, extension and outreach materials should be written at a basic level. It also would be helpful to work with local leaders within the community to help distribute written materials and/or to organize workshops. Additionally, conservation tillage and soil health 
research and outreach efforts should be adapted to farmers who rely on horse-drawn implements [51].

Our findings can be used to improve the design of formal scientific research on organic corn production (and for studies of organic cash grain systems more generally) to ensure they are representative of the actual practices used by organic corn producers. Many published studies that assess the performance of organic corn systems have not adequately represented organic systems. To accurately represent the production approaches used by most organic corn growers in our study states, it would make sense for research trials to utilize livestock manure, diverse crop rotations (including perennial forages), and intensive tillage [53], and to test different organic amendments in combination with organic cultivation practices $[12,54]$. Given that organic corn growers in this region are usually livestock producers, future organic grain research that explores the dynamics of integrated crop-livestock systems would be of value to many producers. In terms of economic research, the integrated nature of many organic corn farming systems should be taken into account so that complementarities are recognized [46].

\section{Conclusions}

Our findings illustrate that organic farmers in this region use a wide range of management practices that have implications for their sustainability footprint. Organic farmers valued multiple aspects of soil health and typically managed fertility and soil health through the use of on-farm manure, incorporating perennials (most common among livestock farmers) and/or cover crops, which can be positives for sustainability. However, organic farmers continue to rely on heavy use of tillage, which can undermine potential soil health benefits. Efforts to develop methods of conservation tillage that are compatible with organic management systems would appear to be a high priority to improve environmental sustainability outcomes. For the vast majority of organic farmers in our study, net returns were positive, which supports social and economic sustainability; however, performance was variable and more exploration is needed to better understand the net benefits of the use of various organic purchased inputs. Finally, from a social and economic sustainability perspective, organic farms in this region appear to have resisted global trends toward conventionalization of the organic sector, with a high proportion of small- and moderate-scale operations that raise a diverse range of crops and livestock. The majority of organic farmers were members of conservative Amish or Plain communities and relied on horses for field operations, which suggests that organic production and marketing are of particular value to those farming communities. The findings can help agricultural service providers, policymakers, and researchers better target their efforts to the specific needs and production systems found on working organic farms in this region.

Supplementary Materials: The following are available online at https:/ /www.mdpi.com/article/10 .3390 / su13168682/s1, Table S1: Survey response rate by state and overall; Table S2: Percentage of respondents raising different types of commodities as certified or non-certified products; Table S3. Characteristics of organic corn growers, overall and by state; Methodology used to estimate the most important source of farm income when missing; Assumptions behind Economic Analysis; Table S4: Assumed cost of various inputs used to impute economic costs where market value information was missing for particular farms; Table S5: Comparison with USDA estimates for organic corn production expenses $\left(\$ \mathrm{ha}^{-1}\right)$; Copy of survey instrument.

Author Contributions: Conceptualization, C.B., D.J.-S., S.K., S.C., C.H. and D.D.; Data curation, C.B., D.J.-S. and S.K.; Methodology D.J.-S.; Formal analysis D.J.-S. and S.K.; Investigation, C.B., D.J.-S. and S.K.; Resources, C.B. and D.J.-S.; Data curation, D.J.-S., C.B. and S.K.; Writing-original draft preparation, C.B. and D.J.-S.; Writing-review and editing, C.B., D.J.-S., S.K., S.C., C.H. and D.D.; Supervision, D.J.-S.; Funding acquisition, D.D. All authors have read and agreed to the published version of the manuscript. 
Funding: This research was funded by Organic Agriculture Research \& Extension funding grant no. 2014-51300- 22331/project accession no. 1003905 from the USDA National Institute of Food and Agriculture.

Institutional Review Board Statement: The study was conducted according to the guidelines of the Declaration of Helsinki and approved by the Institutional Review Board (or Ethics Committee) of The Ohio State University (2017E0806 approved 21 December 2017).

Informed Consent Statement: Informed consent was obtained from all subjects involved in the study.

Data Availability Statement: The data are not publicly available due to agreements made by the Institutional Review Board of the Ohio State University.

Acknowledgments: We appreciate the organic corn farmers who completed the survey and shared their experiences and views of organic corn farming in this region.

Conflicts of Interest: The authors declare no conflict of interest. The funders had no role in the design of the study; in the collection, analyses, or interpretation of data; in the writing of the manuscript; or in the decision to publish the results.

\section{References}

1. Organic Trade Association. U.S. Organic Sales Soar to New High of Nearly \$62 Billion in 2020. Available online: https:/ / ota.com/news/press-releases/21755 (accessed on 5 July 2021).

2. United States Department of Agriculture. Economic Research Services. Organic Market Summary and Trends. Available online: https:/ / www.ers.usda.gov/topics/natural-resources-environment/organic-agriculture/organic-market-summary-andtrends / (accessed on 5 July 2021).

3. McBride, W.D.; Greene, C. A comparison of conventional and organic milk production systems in the US. In Proceedings of the American Agricultural Economics Association Annual Meeting, Portland, OR, USA, 29 July-1 August 2007.

4. United States Department of Agriculture. National Agricultural Statistics Service, National Certified Organic Survey 2016 Summary. 2017. Available online: https://www.nass.usda.gov/Publications/Todays_Reports/reports/census17.pdf (accessed on 5 July 2021).

5. United States Department of Agriculture. National Agricultural Statistics Service. Certified Organic Survey State Publications. Available online: https://www.nass.usda.gov/Surveys/Guide_to_NASS_Surveys/Organic_Production/2016_State_ Publications /index.php (accessed on 30 May 2021).

6. United States Department of Agriculture. Economic Research Services. Feed grains Sector at a Glance. Available online: https:/ / www.ers.usda.gov/topics/crops/corn-and-other-feedgrains/feedgrains-sector-at-a-glance/ (accessed on 6 July 2021).

7. McBride, W.D.; Greene, C.; Foreman, L.; Ali, M. The profit potential of certified organic field crop production. Econ. Res. Rep. ERR-188 2015. [CrossRef]

8. Röös, E.; Bajzelj, B.; Weil, C.; Andersson, E.; Bossio, D.; Gordon, L.J. Moving beyond organic-A food system approach to assessing sustainable and resilient farming. Glob. Food Secur. 2021, 28, 100487. [CrossRef]

9. Beach, H.M.R.; Thapa, R.; Tully, K.L. Soil organic carbon is affected by organic amendments, conservation tillage, and cover cropping in organic farming systems: A meta-analysis. Agric. Ecosyst. Environ. 2021, 312, 107356. [CrossRef]

10. Lynch, D.H.; MacRae, R.; Martin, R.C. The Carbon and Global Warming Potential Impacts of Organic Farming: Does It Have a Significant Role in an Energy Constrained World? Sustainability 2011, 3, 322-362. [CrossRef]

11. Schonbeck, M. Soil Health and Organic Farming; Organic Farming Research Foundation: Santa Cruz, CA, USA, 2017.

12. Spargo, J.T.; Cavigelli, M.A.; Mirsky, S.B.; Meisinger, J.J.; Ackroyd, V.J. Organic Supplemental Nitrogen Sources for Field Corn Production after a Hairy Vetch Cover Crop. Agron. J. 2016, 108, 1992-2002. [CrossRef]

13. Tian, X.; Fan, H.; Zhang, F.; Wang, K.; Ippolito, J.; Li, J.; Jiao, Z.; Li, Y.; Li, Y.; Su, J. Soil carbon and nitrogen transformations under soybean as influenced by organic farming. Agron. J. 2018, 110, 1883-1892. [CrossRef]

14. Williams, D.M.; Blanco-Canqui, H.; Francis, C.A.; Galusha, T.D. Organic farming and soil physical properties: An assessment after 40 years. Agron. J. 2017, 109, 600-609. [CrossRef]

15. Beach, H.M.; Laing, K.W.; Walle, M.V.D.; Martin, R.C. The Current State and Future Directions of Organic No-Till Farming with Cover Crops in Canada, with Case Study Support. Sustainability 2018, 10, 373. [CrossRef]

16. Archer, D.W.; Jaradat, A.A.; Johnson, J.M.F.; Weyers, S.L.; Gesch, R.W.; Forcella, F.; Kludze, H.K. Crop productivity and economics during the transition to alternative cropping systems. Agron. J. 2007, 99, 1538-1547. [CrossRef]

17. Smith, R.G.; Barbercheck, M.E.; Mortensen, D.A.; Hyde, J.; Hulting, A.G. Yield and net returns during the transition to organic feed grain production. Agron. J. 2011, 103, 51-59. [CrossRef]

18. McGee, J.A.; Alvarez, C. Sustaining without Changing: The Metabolic Rift of Certified Organic Farming. Sustainability 2016, 8 , 115. [CrossRef]

19. Foreman, L. Characteristics and production costs of US corn farms, including organic, 2010. USDA-ERS Econ. Inf. Bull. 2014. [CrossRef] 
20. Rover, O.J.; da Silva Pugas, A.; De Gennaro, B.C.; Vittori, F.; Roselli, L. Conventionalization of Organic Agriculture: A Multiple Case Study Analysis in Brazil and Italy. Sustainability 2020, 12, 6580. [CrossRef]

21. Guthman, J. Agrarian Dreams: The Paradox of Organic Farming in California, 2nd ed.; University of California Press: Oakland, CA, USA, 2014.

22. Goldberger, J. Conventionalization, civic engagement, and the sustainability of organic agriculture. J. Rural Stud. 2011, 27, 288-296. [CrossRef]

23. Gopinath, K.A.; Saha, S.; Mina, B.; Pande, H.; Kundu, S.; Gupta, H. Influence of organic amendments on growth, yield and quality of wheat and on soil properties during transition to organic production. Nutr. Cycl. Agroecosyst. 2008, 82, 51-60. [CrossRef]

24. United States Department of Agriculture. Agricultural Marketing Service. Available online: https://organic.ams.usda.gov/ integrity / (accessed on 5 July 2021).

25. Dillman, D.A.; Smyth, J.D.; Christian, L.M. Internet, Phone, Mail, and Mixed-Mode Surveys: The Tailored Design Method, 4th ed.; John Wiley: Hoboken, NJ, USA, 2014.

26. Delate, K.; DeWitt, J. Building a farmer-centered land grant university organic agriculture program: A Midwestern partnership. Renew. Agric. Food Syst. 2004, 19, 80-91. [CrossRef]

27. Constance, D.H.; Choi, J.Y.; Lara, D. Social Dimensions of Organic Production and Systems Research. Crop Manag. 2013, 12, 1-10. [CrossRef]

28. Carolan, M. Barriers to the adoption of sustainable agriculture on rented land: An examination of contesting social fields. Rural Sociol. 2005, 70, 387. [CrossRef]

29. Hayden, J.; Rocker, S.; Phillips, H.; Heins, B.; Smith, A.; Delate, K. The Importance of Social Support and Communities of Practice: Farmer Perceptions of the Challenges and Opportunities of Integrated Crop-Livestock Systems on Organically Managed Farms in the Northern U.S. Sustainability 2018, 10, 4606. [CrossRef]

30. Cross, J.A. Change and sustainability issues in America's Dairyland. Focus Geogr. 2015, 58, 173-183. [CrossRef]

31. Donnermeyer, J. Doubling Time and Population Increase of the Amish. J. Amish Plain Anabapt. Stud. 2015, 3, 94-109. [CrossRef]

32. McConnell, D.; Loveless, M. Nature and the Environment in Amish Life; John Hopkins University Press: Baltimore, MD, USA, 2018; p. 294.

33. United States Department of Agriculture. Agricultural Prices (Monthly Report). Available online: https://usda.library.cornell. edu/concern/publications/c821gj76b?locale=en (accessed on 8 August 2020).

34. Ohio State University Extension Farm Office. Corn Production Budget. 2020. Available online: https://farmoffice.osu.edu/farmmgt-tools / farm-budgets (accessed on 8 August 2020).

35. Appelgate, S.R.; Lenssen, A.W.; Wiedenhoeft, M.H.; Kaspar, T.C. Cover crop options and mixes for upper midwest corn-soybean systems. Agron. J. 2017, 109, 968-984. [CrossRef]

36. Blanco-Canqui, H.; Shaver, T.M.; Lindquist, J.L.; Shapiro, C.A.; Elmore, R.W.; Francis, C.A.; Hergert, G.W. Cover crops and ecosystem services: Insights from studies in temperate soils. Agron. J. 2015, 107, 2449-2474. [CrossRef]

37. Sprunger, C.D.; Culman, S.W.; Deiss, L.; Brock, C.; Jackson-Smith, D. Which management practices influence soil health in Midwest organic corn systems? Agron. J. 2021. [CrossRef]

38. Arbuckle, J.G.; Roesch-McNally, G. Cover crop adoption in Iowa: The role of perceived practice characteristics. J. Soil Water Conserv. 2015, 70, 418-429. [CrossRef]

39. Roesch-McNally, G.; Arbuckle, J.G.; Tyndall, J.C. Soil as Social-Ecological Feedback: Examining the "Ethic" of Soil Stewardship among Corn Belt Farmers. Rural Sociol. 2018, 83, 145-173. [CrossRef]

40. Triplett, G.B., Jr;; Dick, W.A. No-Tillage Crop Production: A Revolution in Agriculture! Agron. J. 2008, 100, S-153-S-165. [CrossRef]

41. Givens, W.A.; Shaw, D.R.; Kruger, G.R.; Johnson, W.G.; Weller, S.C.; Young, B.G.; Wilson, R.G.; Owen, M.D.K.; Jordan, D. Survey of Tillage Trends Following The Adoption of Glyphosate-Resistant Crops. Weed Technol. 2009, 23, 150-155. [CrossRef]

42. Kempf, J. Quality Agriculture; Regenerative Agriculture Publishing: Moline, IL, USA, 2020.

43. Kinsey, N.; Walters, C. Neal Kinsey's Hands-On Agronomy: Feeding E Balancing Your Soil; Acres U.S.A. Press: Austin, TX, USA, 2006.

44. Zimmer, G.; Zimmer-Durand, L. The Biological Farmer: A Complete Guide to the Sustainable and Profitable Biological System of Farming; Acres U.S.A.: Austin, TX, USA, 2017; p. 518.

45. Silva, E.M.; Moore, V.M. Cover Crops as an Agroecological Practice on Organic Vegetable Farms in Wisconsin, USA. Sustainability 2017, 9, 55. [CrossRef]

46. de Roest, K.; Ferrari, P.; Knickel, K. Specialisation and economies of scale or diversification and economies of scope? Assessing different agricultural development pathways. J. Rural Stud. 2018, 59, 222-231. [CrossRef]

47. Keene, C.L.; Curran, W.S.; Wallace, J.M.; Ryan, M.R.; Mirsky, S.B.; VanGessel, M.J.; Barbercheck, M.E. Cover crop termination timing is critical in organic rotational no-till systems. Agron. J. 2017, 109, 272-282. [CrossRef]

48. Liebman, A.M.; Grossman, J.; Brown, M.; Wells, M.S.; Reberg-Horton, S.C.; Shi, W. Legume cover crops and tillage impact nitrogen dynamics in organic corn production. Agron. J. 2018, 110, 1046-1057. [CrossRef]

49. Larson, C.D.; Menalled, F.D.; Lehnhoff, E.A.; Seipel, T. Plant community responses to integrating livestock into a reduced-till organic cropping system. Ecosphere 2021, 12, e03412. [CrossRef]

50. Culman, S.W.; Brock, C.; Doohan, D.; Jackson-Smith, D.; Herms, C.; Chaganti, V.N.; Kleinhenz, M.; Sprunger, C.D.; Spargo, J. Base cation saturation ratios vs. sufficiency level of nutrients: A false dichotomy in practice. Agron. J. 2021. [CrossRef] 
51. Brock, C.; Ulrich-Schad, J.D.; Prokopy, L. Bridging the Divide: Challenges and Opportunities for Public Sector Agricultural Professionals Working with Amish and Mennonite Producers on Conservation. Environ. Manag. 2018, 61, 756-771. [CrossRef]

52. Beaudreault, A.; Jepsen, D.; Dellinger, W. Designing an Agricultural Safety Intervention Program for Ohio Amish Youth. Cases Public Health Commun. Mark. 2009, 3, 38-58.

53. Delate, K.; Cambardella, C.A. Agroecosystem performance during transition to certified organic grain production. Agron. J. 2004 96, 1288-1298. [CrossRef]

54. West, J.R.; Ruark, M.D.; Bussan, A.J.; Colquhoun, J.B.; Silva, E.M. Nitrogen and Weed Management for Organic Sweet Corn Production on Loamy Sand. Agron. J. 2016, 108, 758-769. [CrossRef] 